\title{
Impact of the "Chalk" on perceived visual quality and the willingness to climb: a research on sports climbing
}

\author{
Güney Çetinkaya ${ }^{1 \mathrm{ABCDE}}$, Abdullah Güngör ${ }^{1 \mathrm{BCDE}}$, Dicle Aras ${ }^{2 \mathrm{BCD}}$ \\ ${ }^{1}$ Akdeniz University, Faculty of Sports Sciences, Turkey \\ ${ }^{2}$ Ankara University, Faculty of Sports Sciences, Turkey
}

Authors' Contribution: A - Study design; B - Data collection; C - Statistical analysis; D - Manuscript Preparation; E - Funds Collection

\begin{abstract}
Purpose: $\quad$ Rock climbing is a popular outdoor recreation and tourism activity practiced in natural areas. Rock climbing, like all of the other outdoor activities, has a variety of impacts on nature and visitors. Understanding these impacts is important for ensuring the sustainability of natural environments and activities practiced in these areas. The goal of this study was to analyze the impacts of chalk density on the rock surface, on the perceived visual quality and the willingness of participants to climb.

Material: $\quad$ The visual research method was used in the study to analyze the perceived visual quality of climbers. Photographing technique, one of the visual research methods, was utilized in the study to determine the perceived visual quality of climbers. Eleven photographs, prepared for this purpose, were presented to 213 voluntary participants and the obtained results were evaluated.

Results: $\quad$ Repeated measures analysis of variance test results indicate that the chalk level increase specifically designed and presented in the photographs statistically changed the perceived visual quality of participants. Impacts of the variables of gender, climbing experience, climbing level and chalk density level on perceived visual quality are compared with the ANOVA test. The results indicate that withingroup variance in terms of the climbing level is statistically significant.

Conclusions: $\quad$ According to the results of the study, the increase in chalk use density on rock surfaces has a negative impact on the perceived visual quality and willingness of participants to climb.

Keywords: sports climbing, visual impacts, chalk, willingness to climb, perceived visual quality
\end{abstract}

\section{Introduction}

Demand for modern societies on outdoor recreations, which is a significant component of today's lifestyle, has dramatically increased in the last decade; these activities have become important for people living in even the most remote and pristine areas. Rock climbing is one of these activities which have drastically increased in recent years [1]. Many industrialized societies, particularly living in the U.S.A and Europe, have been showing an increasing interest in this activity. For instance, while there were 25 million of climbers in the U.S.A in 2008, this number will increase to $38-48$ million by 2060 according to the estimations. On the other hand, it is predicted that the number of days in which climbing is practiced by these climbers per year will increase to 178-219 million [2]. The number of active climbers in Europe is more than two million and this number is increasing every day [3]. Owing to this increasing interest, rock surfaces which were once unapproachable now have to face unprecedented human pressure [1]. Although the popularity of this activity has been increasing, there are only a limited number of scientific/academic studies about the effects of this activity [4]. Most of the studies analysing the issue have focused on the changes in the structure and composition of vegetation structure on rock surfaces [5]. Although the impacts of rock climbing are not completely clear, current studies have indicated that vegetation on the rock surface is negatively affected by this increasingly popular activity ๑) Güney Çetinkaya, Abdullah Güngör, Dicle Aras, 2021

doi:10.15561/26649837.2021.0103
$[1,6,7]$. On the other hand, the systematic compilation study by Holzschuh [8] indicates that lichens and plant species on rock surfaces can sometimes be negatively or positively affected by the activity according to variables, while snail diversity is negatively affected. In addition to these, Holzschuh [8] determined that the studies about the effects of rock climbing on bird diversity are limited. According to the researcher's findings, bryophytes are not affected by the activity. Holzschuh [8] states that there is not a single, commonly accepted idea or data about the impacts of rock climbing and it is necessary to conduct more studies focusing on determining, analysing and understanding these impacts.

Besides the effects of rock climbing on bio-diversity, the activity affects different dimensions of natural and human life. These effects can be classified by chipping and other mechanical wears such as polishing; the impact of chocks, pitons, and bolts; increased rock-fall rate; and mainly aesthetic damage caused by chalk and rope wear on soft rocks [9]. Aesthetic damages of outdoor activities on nature not only affect the environment but also change the experiences of visitors. Aesthetic factors and visual beauty have an impact on visitor preferences about outdoor activities; these factors direct tendencies and willingness of visitors. There is a direct, undeniable relationship between the wish of visiting a natural environment and the visual beauty and quality of that area [10]. On the other hand, the related studies in the literature indicate that visual beauty is one of the most important 
factors that affect the destination choices of outdoor recreation participators [11]. Owing to the reason, it is highly important to determine the factors that affect the visual quality or beauty for ensuring the sustainability of a destination. Unfortunately, there are only a limited number of studies focusing on the visual impacts of rock climbing [12]. Studies about the issue mostly focus on the visual impacts of fixed (bolt/piton) and mobile anchors. The studies in the related literature indicate that the anchors negatively affect the visual quality of rocks [1315]. It is determined that the executives in various regions in the U.S.A either prohibited the use of fixed and mobile anchors in various rock climbing areas in the 1990s [12], or set some specific rules about the use of these materials during climbing.

Another negative visual effect of rock climbing results from the use of Magnesium Carbonate, known as "Chalk". This material has a white colour and it is a kind of powder; climbers use the powder to prevent their hands from sweating and to create a friction between their hands and rock surfaces $[16,17]$. Magnesium carbonate is traditionally carried in a belt bag called "chalk bag". Climber puts his/her fingers in this bag, take some powder and climbs; every touch/grip leaves a white stain on the surface of rocks. Although this visual effect of chalk use is defined as "irritating" by climbers [18], the results of the studies on the issue indicate that the use of the material does not cause a statistically significant visual effect $[12,19]$. At this point, it is important to note that while previous studies on the topic focused on situation assessment about chalk use, they didn't take the effect of the increase in chalk use into consideration. This is why; there is no data in the literature about the visual on climbing routes resulting from the increase in chalk use. The goal of this current study was to analyze the effects of the increasing chalk use on rock surfaces on perceived visual quality and the willingness of participants to climb.

\section{Material and Methods}

\section{Sources of information.}

The visual research method is used in the study to analyze the perceived visual quality of climbers. This method has been playing a significant role for a long time in the environment and natural resources studies. There are many studies especially on analysing environmental effects of recreational and touristic activities through the use of visual research method [20-24]. Photographs processed by computers have been used in recent studies for assessing quality standards about visitor experiences and specific components in outdoors [25]. A variety of studies support the relationship between the photographic evaluation method and direct (onsite) judgments of visitors. It is determined that the overlap ratio between the two methods is more than $80 \%[26,27]$.

A photograph of the sports climbing route taken by researchers is used in this study; Antalya - Olympus Sports Climbing Area is chosen as the study field. Route photograph angle, the surface of climbing and framing consistency, excluding any kind of foreign objects in the image, clarity of handles on the rock surfaces and climbing route are the criteria taken into consideration during the process of determining the route. The photograph determined for the research is transferred into a photoediting program in the computer; magnesium carbonate marks on the climbing surface are cleaned with the same program. After these steps, magnesium carbonate marks are increased layer by layer, and a total of 11 different photographs with different magnesium carbonate layers are carefully formed.

\section{Procedure}

Sport climbing is the one of the most preferred and demanded branch of climbing therefore the sample was selected from in the sports climbers. Participator survey approach used in the related previous studies is used for determining the perceived visual quality of rock climbers in this study $[28,29]$. The survey form prepared in the digital media is e-mailed to the sports climbing trainers and sportsmen who are members of the Turkish Mountaineering Federation. A total of 11 slides in a specific order in the survey are shown to the participators. They are required to evaluate each photograph in these slides according to two different types of 7 Point Likert scales. In the first evaluation stage, questions prepared for determining perceived visual quality are asked (1 point-very low visual quality and 7 points-very high visual quality). In the second evaluation stage, questions about the willingness to climb the route presented in the photographs are asked (1 point- I absolutely don't prefer to climb, 7 points- I absolutely prefer to climb). Questions prepared for the purpose of determining the demographic features of participators are presented in the last section of the survey.

Statistical Analysis:

Kolmogorov Smirnov test is used as the test of normalcy for evaluating the normality assumption of the data. Skewness and Kurtosis values of the obtained data are analyzed. According to the results, there is a normal distribution [30]. Frequency and means are commonly used for summarizing the data in visual research methods [31] are completed. As the study results are more complicated than the results obtained from the summaries of frequencies and means [32], ANOVA test is used for repeated measures analysis while Independent t-test is used for paired comparison tests.

\section{Results}

213 rock climbers voluntarily participated in the research. Fifty-nine participants are female while 154 participants are male (mean age: $31.44 \pm 9.84$ years). Most of the participants have been practicing the activity for 1-5 years $(49.3 \%)$. It is determined that most of the climbers who participated in the study have advanced (Classified by Draper et al. [33]) level climbing experience (see Table 1). Changes in the perceived visual quality of participants are measured with 11 photographs. It is determined that the obtained data is normally distributed. Repeated measures analysis of variance [(ANOVA (Greenhouse-Geisser)] test results indicates that the chalk level increase specifically 
designed and presented in the photographs statistically changed the perceived visual quality of participants $[F(1.95,412.54)=69.65, p<.01]$. According to the Post hoc test result, based on Bonferroni correction, perceived visual quality score means of participants decreased from 4.95 (the first photo) to 2.98 (the last photo) (see Table 2). The results of the study show that the perceived visual quality of participants started to become negative with the photograph no.6 (Chalk density: 5 layers) (see Figure 1). Impacts of the variables of gender, climbing experience, climbing level and chalk density level on perceived visual quality are compared with the ANOVA test. The results indicate that within-group variance in terms of the climbing level is statistically significant [F (1.96, 408.91 $)=3.69, \mathrm{p}<.05]$. An increase in the chalk density in photos causes a decrease in perceived visual quality means of every group (Intermediate and lower, advanced and higher) (see Figure 2). According to the paired comparisons, there are not statistically significant results between two groups in the photos from 1 to 9 ( $p>.05$ ); on the other hand, participants in the group 'advanced and higher' have lower perceived visual quality means in the 10th and 11th photos when compared to the other group (see Table 3) $(\mathrm{p}<.05)$.

Changes in willingness of participant to climb on the basis of the chalk effect are measured with 11 specifically prepared photos. Results of repeated-measures analysis of variance [(ANOVA (Greenhouse-Geisser)] test indicate that the chalk level increase presented in the photographs statistically changed the climbing willingness of

Table 1. Demographic Features

\begin{tabular}{llllllllllll}
\hline Gender & $\mathbf{n}$ & $\mathbf{\%}$ & Age & $\mathbf{n}$ & $\mathbf{\%}$ & Climbing Level & $\mathbf{n}$ & $\mathbf{\%}$ & $\begin{array}{l}\text { Climbing } \\
\text { Experience }\end{array}$ & $\mathbf{n}$ & $\mathbf{\%}$ \\
\hline Male & 154 & 27.7 & $18-25$ & 58 & 27.2 & Lower Grade & 5 & 2.3 & $1-5$ years & 105 & 49.3 \\
Female & 59 & 72.3 & $26-34$ & 74 & 34.7 & Intermediate & 97 & 45.5 & $6-10$ years & 53 & 24.9 \\
& & & $35-44$ & 28 & 13.1 & Advanced & 102 & 47.9 & 10 years< & 55 & 25.8 \\
& & & $45-54$ & 13 & 6.1 & Elite & 6 & 2.8 & & & \\
\hline
\end{tabular}

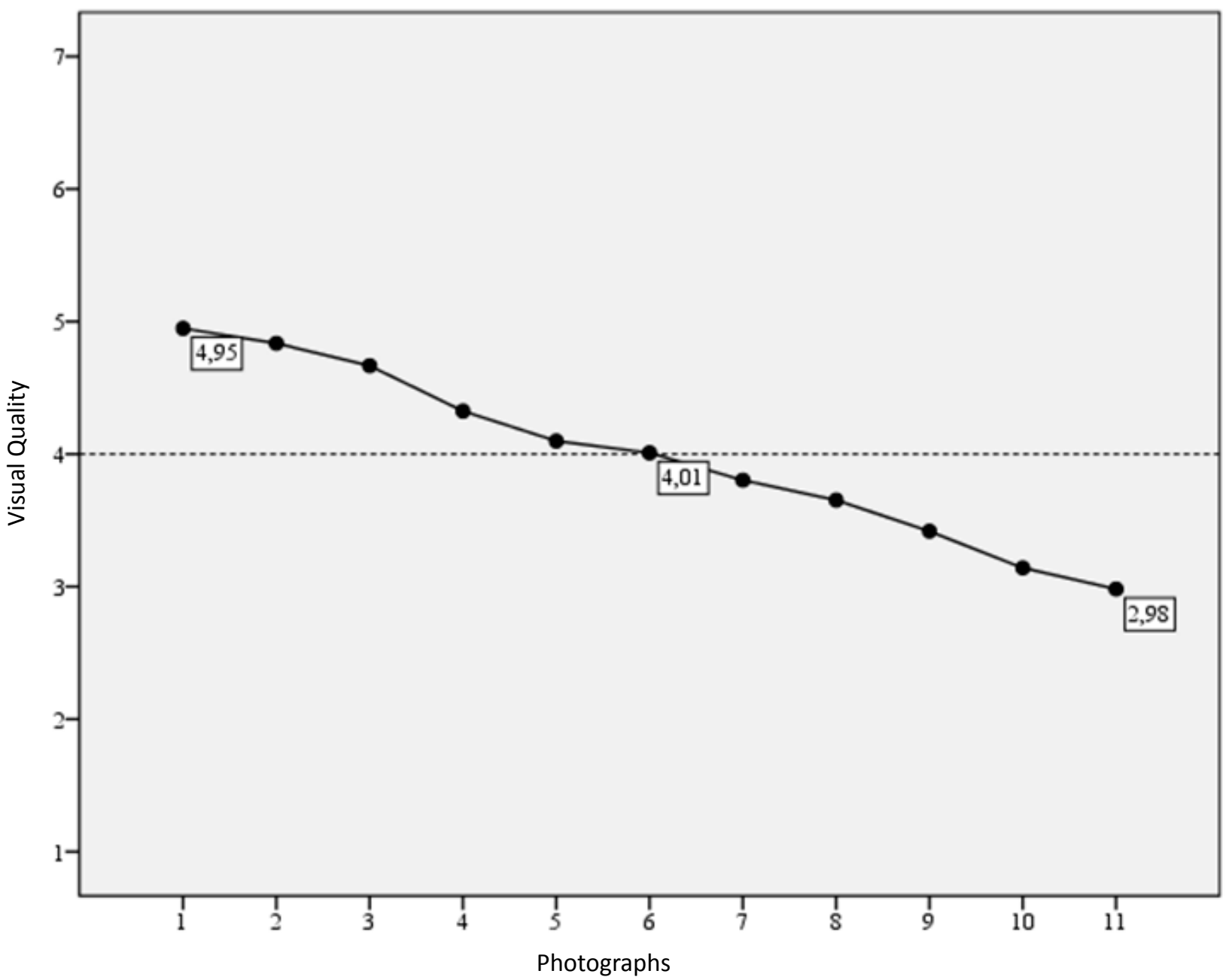

Figure 1. Curve of photographic visual quality of participants (Chalk density effect) 
participants $[\mathrm{F}(1.95,414.15)=39.21, \mathrm{p}<.01]$. According to the Post hoc test result, based on Bonferroni correction, participant climbing willingness means decreased from 5.20 (the first photo) to 3.79 (the last photo) (See Table 4). The results of the study show that the climbing willingness of participants started to be negatively affected by the photograph no.10 (Chalk density: 9 layers) (see
Figure 3). Impacts of the variables of gender, climbing experience, climbing level and chalk density level on climbing willingness are compared with the ANOVA test. The results indicate that within-group variance in terms of the climbing level is statistically significant [F (1.96, 408.43 $=4.08, \mathrm{p}<.05)$. An increase in the chalk density in photos causes a decrease in the means of every group

Table 2. ANOVA comparisons of visual quality perceptions of participants about chalk effect

\begin{tabular}{|c|c|c|c|c|c|c|c|c|c|c|c|c|c|}
\hline & \multicolumn{2}{|c|}{ Variables } & \multicolumn{11}{|c|}{ Bonferroni Comparisons* } \\
\hline & Mean & SD & 1 & 2 & 3 & 4 & 5 & 6 & 7 & 8 & 9 & 10 & 11 \\
\hline 1 & 4.95 & 1.70 & & & & & & & & & & & \\
\hline 2 & 4.84 & 1.48 & 1.00 & & & & & & & & & & \\
\hline 3 & 4.67 & 1.48 & .24 & .54 & & & & & & & & & \\
\hline 4 & 4.32 & 1.57 & .00 & .00 & .00 & & & & & & & & \\
\hline 5 & 4.10 & 1.67 & .00 & .00 & .00 & .00 & & & & & & & \\
\hline 6 & 4.01 & 1.74 & .00 & .00 & .00 & .00 & .63 & & & & & & \\
\hline 7 & 3.80 & 1.79 & .00 & .00 & .00 & .00 & .00 & .00 & & & & & \\
\hline 8 & 3.65 & 1.80 & .00 & .00 & .00 & .00 & .00 & .00 & .00 & & & & \\
\hline 9 & 3.42 & 1.89 & .00 & .00 & .00 & .00 & .00 & .00 & .00 & .00 & & & \\
\hline 10 & 3.14 & 1.96 & .00 & .00 & .00 & .00 & .00 & .00 & .00 & .00 & .00 & & \\
\hline 11 & 2.98 & 2.10 & .00 & .00 & .00 & .00 & .00 & .00 & .00 & .00 & .00 & .01 & \\
\hline
\end{tabular}

*p-value

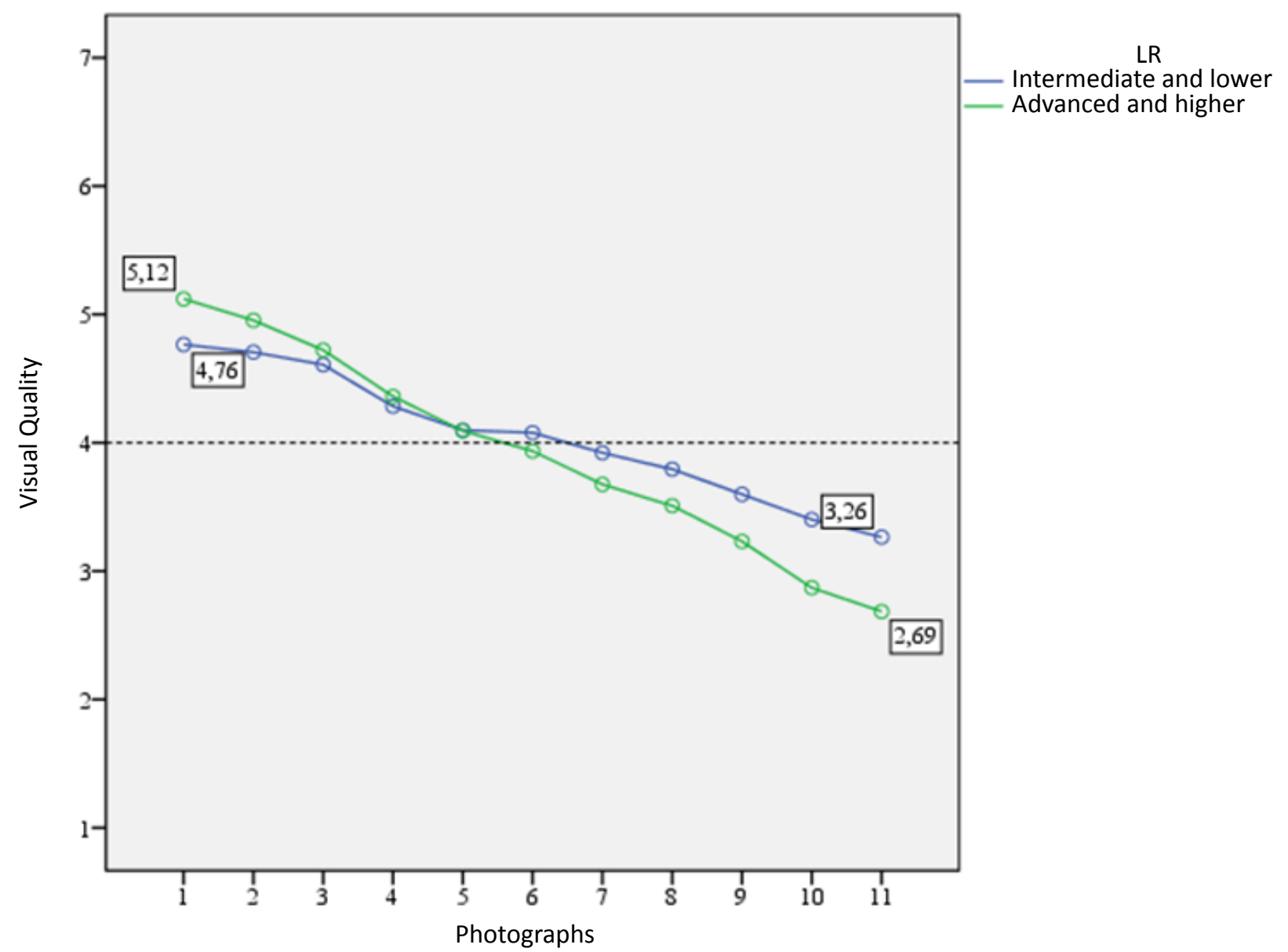

Figure 2. Curve of visual quality of participant according to climber proficiency on the basis of photographs (Chalk density effect) 
Table 3. Results of Independent Group t-test conducted for determining if the perceived visual quality of participators changed according to the climbing level variable

\begin{tabular}{|c|c|c|c|c|c|c|c|}
\hline Photo & Groups & $\mathbf{N}$ & Mean & Std. Deviation & $\mathbf{t}$ & df & $\mathbf{p}$ \\
\hline \multirow{2}{*}{ Photo 1} & Group I & 102 & 4.76 & 1.70 & \multirow{2}{*}{-0.52} & \multirow{2}{*}{208} & \multirow{2}{*}{0.13} \\
\hline & Group II & 108 & 5.12 & 1.69 & & & \\
\hline \multirow{2}{*}{ Photo 2} & Group I & 102 & 4.71 & 1.48 & \multirow{2}{*}{-0.22} & \multirow{2}{*}{208} & \multirow{2}{*}{0.23} \\
\hline & Group II & 108 & 4.95 & 1.47 & & & \\
\hline \multirow{2}{*}{ Photo 3} & Group I & 102 & 4.61 & 1.46 & \multirow{2}{*}{-0.56} & \multirow{2}{*}{208} & \multirow{2}{*}{0.58} \\
\hline & Group II & 108 & 4.72 & 1.50 & & & \\
\hline \multirow{2}{*}{ Photo 4} & Group I & 102 & 4.28 & 1.61 & \multirow{2}{*}{-0.35} & \multirow{2}{*}{208} & \multirow{2}{*}{0.73} \\
\hline & Group II & 108 & 4.36 & 1.55 & & & \\
\hline \multirow{2}{*}{ Photo 5} & Group I & 102 & 4.10 & 1.77 & \multirow{2}{*}{0.02} & \multirow{2}{*}{208} & \multirow{2}{*}{0.98} \\
\hline & Group II & 108 & 4.09 & 1.60 & & & \\
\hline \multirow{2}{*}{ Photo 6} & Group I & 102 & 4.08 & 1.86 & \multirow{2}{*}{0.59} & \multirow{2}{*}{208} & \multirow{2}{*}{0.55} \\
\hline & Group II & 108 & 3.94 & 1.63 & & & \\
\hline \multirow{2}{*}{ Photo 7} & Group I & 102 & 3.92 & 1.90 & \multirow{2}{*}{0.99} & \multirow{2}{*}{208} & \multirow{2}{*}{0.32} \\
\hline & Group II & 108 & 3.68 & 1.68 & & & \\
\hline \multirow{2}{*}{ Photo 8} & Group I & 102 & 3.79 & 1.90 & \multirow{2}{*}{1.14} & \multirow{2}{*}{208} & \multirow{2}{*}{0.26} \\
\hline & Group II & 108 & 3.51 & 1.72 & & & \\
\hline \multirow{2}{*}{ Photo 9} & Group I & 102 & 3.60 & 2.00 & \multirow{2}{*}{1.41} & 208 & 016 \\
\hline & Group II & 108 & 3.23 & 1.78 & & & 0.10 \\
\hline Photo 10 & Group I & 102 & 3.40 & 2.03 & & 208 & $005 *$ \\
\hline ondo & Group II & 108 & 2.87 & 1.89 & 1.91 & 200 & 0.05 \\
\hline Photo 11 & Group I & 102 & 3.26 & 2.11 & 205 & & $00 \Delta *$ \\
\hline Photo 11 & Group II & 108 & 2.69 & 1.99 & 2.05 & 208 & $0.04^{\circ}$ \\
\hline
\end{tabular}

Group I- Intermediate and lower; Group II- Advanced and higher

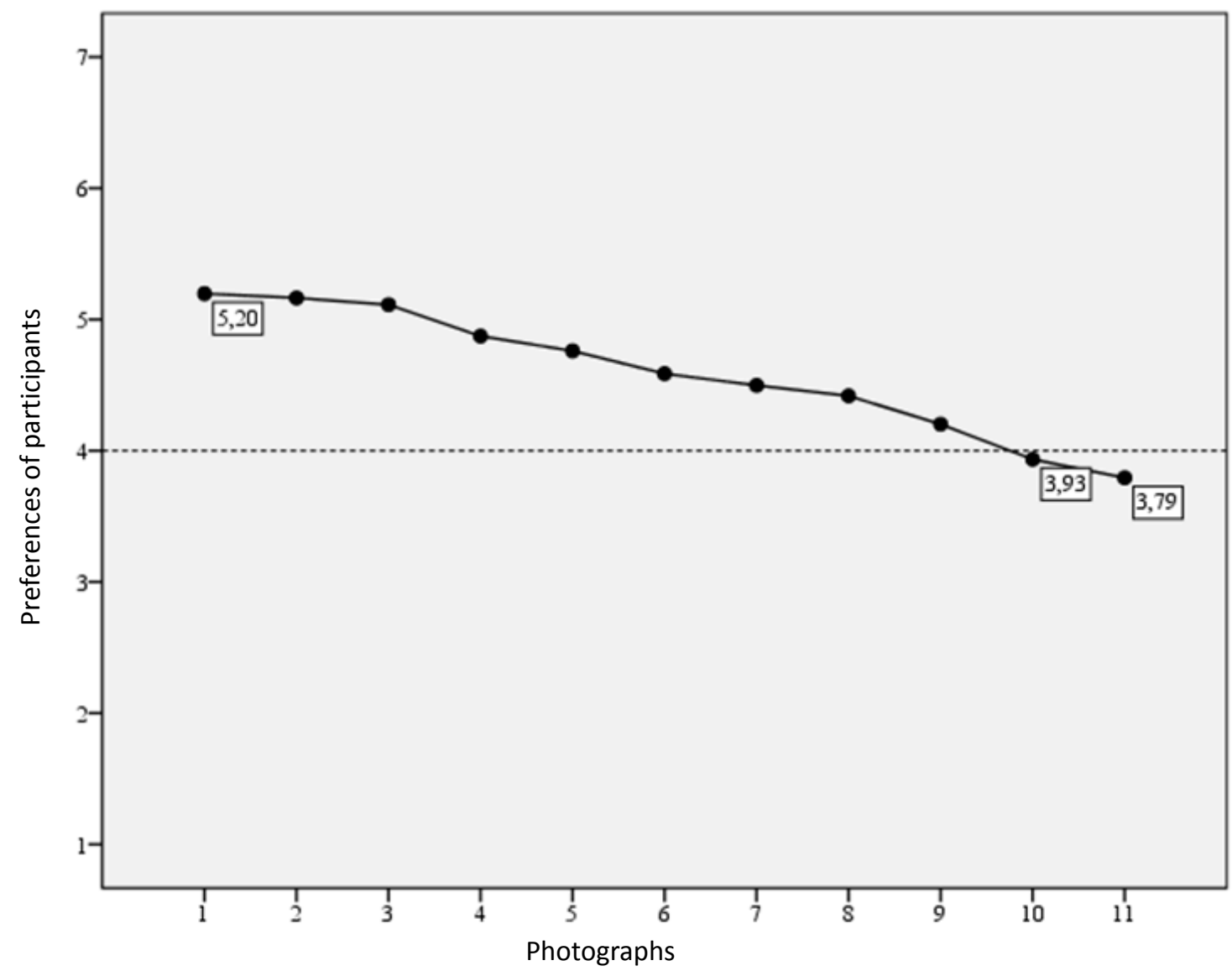

Figure 3. Participant climbing willingness curve on the basis of photographs (Chalk density effect) 
about the willingness to climb (Intermediate and lower, advanced and higher) (see Figure 4). According to the paired comparisons, there are not statistically significant results between the two groups $(\mathrm{p}>.05)$.

\section{Discussion}

Rock climbing is a popular outdoor activity practiced in natural areas. Researching and analysing the impacts of activities based on nature and understanding visitor attitudes are significant for ensuring the sustainability of natural environments in these areas. Specifically reporting the effects of these activities on natural resources will give a direction to administrative norms and practices. Decreasing negative effects may, in turn, increase the number of visitors [19]. An increase in visitor experience and quality of experience significantly and directly affects

Table 4. ANOVA Comparisons of Visual Climbing Preferences of Participants on the basis of Chalk Effect

\begin{tabular}{|c|c|c|c|c|c|c|c|c|c|c|c|c|c|}
\hline & \multicolumn{2}{|c|}{ Variables } & \multicolumn{11}{|c|}{ Bonferroni Comparisons* } \\
\hline & Mean & SD & 1 & 2 & 3 & 4 & 5 & 6 & 7 & 8 & 9 & 10 & 11 \\
\hline 1 & 5.20 & 1.67 & & & & & & & & & & & \\
\hline 2 & 5.16 & 1.51 & 1.00 & & & & & & & & & & \\
\hline 3 & 5.11 & 1.48 & 1.00 & 1.00 & & & & & & & & & \\
\hline 4 & 4.87 & 1.54 & .19 & .02 & .00 & & & & & & & & \\
\hline 5 & 4.76 & 1.69 & .06 & .01 & .00 & 1.00 & & & & & & & \\
\hline 6 & 4.59 & 1.78 & .00 & .00 & .00 & .00 & .00 & & & & & & \\
\hline 7 & 4.50 & 1.81 & .00 & .00 & .00 & .00 & .00 & 1.00 & & & & & \\
\hline 8 & 4.42 & 1.88 & .00 & .00 & .00 & .00 & .00 & .21 & 1.00 & & & & \\
\hline 9 & 4.20 & 1.92 & .00 & .00 & .00 & .00 & .00 & .00 & .00 & .00 & & & \\
\hline 10 & 3.93 & 2.11 & .00 & .00 & .00 & .00 & .00 & .00 & .00 & .00 & .00 & & \\
\hline 11 & 3.73 & 2.20 & .00 & .00 & .00 & .00 & .00 & .00 & .00 & .00 & .00 & .03 & \\
\hline
\end{tabular}

*p-value

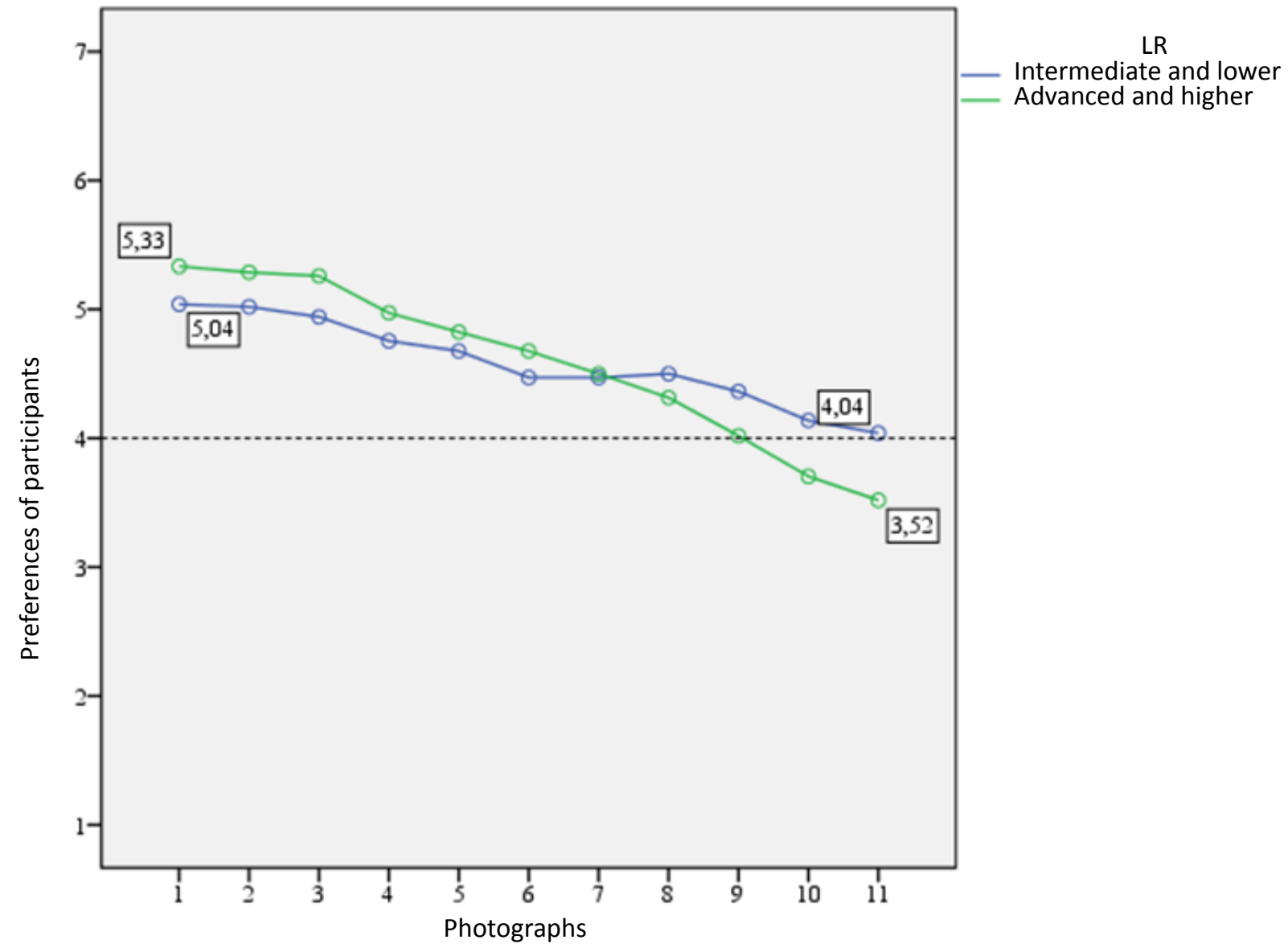

Figure 4. Curve of climbing willingness of participant according to climber proficiency on the basis of photographs (Chalk density effect) 
Table 5. Results of Independent Group t-test conducted for determining if the climbing willingness of participators changed according to the climbing level variable

\begin{tabular}{|c|c|c|c|c|c|c|c|}
\hline Photo & Groups & $\mathbf{N}$ & Mean & Std. Deviation & $t$ & df & $\mathbf{p}$ \\
\hline \multirow{2}{*}{ Photo 1} & Group I & 102 & 5.04 & 1.69 & \multirow{2}{*}{-1.28} & \multirow{2}{*}{208.00} & \multirow{2}{*}{0.20} \\
\hline & Group II & 108 & 5.33 & 1.65 & & & \\
\hline \multirow{2}{*}{ Photo 2} & Group I & 102 & 5.02 & 1.58 & \multirow{2}{*}{-1.29} & \multirow{2}{*}{208.00} & \multirow{2}{*}{0.20} \\
\hline & Group II & 108 & 5.29 & 1.42 & & & \\
\hline \multirow{2}{*}{ Photo 3} & Group I & 102 & 4.94 & 1.53 & \multirow{2}{*}{-1.57} & \multirow{2}{*}{208.00} & \multirow{2}{*}{0.12} \\
\hline & Group II & 108 & 5.26 & 1.40 & & & \\
\hline \multirow{2}{*}{ Photo 4} & Group I & 102 & 4.75 & 1.59 & \multirow{2}{*}{-1.02} & \multirow{2}{*}{208.00} & \multirow{2}{*}{0.31} \\
\hline & Group II & 108 & 4.97 & 1.49 & & & \\
\hline \multirow{2}{*}{ Photo 5} & Group I & 102 & 4.68 & 1.78 & \multirow{2}{*}{-0.63} & \multirow{2}{*}{208.00} & \multirow{2}{*}{0.53} \\
\hline & Group II & 108 & 4.82 & 1.60 & & & \\
\hline \multirow{2}{*}{ Photo 6} & Group I & 102 & 4.47 & 1.86 & \multirow{2}{*}{-0.84} & \multirow{2}{*}{208.00} & \multirow{2}{*}{0.40} \\
\hline & Group II & 108 & 4.68 & 1.70 & & & \\
\hline \multirow{2}{*}{ Photo 7} & Group I & 102 & 4.47 & 1.90 & \multirow{2}{*}{-0.12} & \multirow{2}{*}{208.00} & \multirow{2}{*}{0.91} \\
\hline & Group II & 108 & 4.50 & 1.72 & & & \\
\hline \multirow{2}{*}{ Photo 8} & Group I & 102 & 4.50 & 1.93 & \multirow{2}{*}{0.72} & \multirow{2}{*}{208.00} & \multirow{2}{*}{0.48} \\
\hline & Group II & 108 & 4.31 & 1.82 & & & \\
\hline \multirow{2}{*}{ Photo 9} & Group I & 102 & 4.36 & 1.98 & \multirow{2}{*}{1.27} & חמת פח2 & 021 \\
\hline & Group II & 108 & 4.02 & 1.96 & & 200.00 & 0.21 \\
\hline Photo 10 & Group I & 102 & 4.14 & 2.07 & 149 & 20800 & 0.14 \\
\hline & Group II & 108 & 3.70 & 2.13 & & & \\
\hline Photo 1 & Group I & 102 & 4.04 & 2.13 & 77 & חמ סחמ & ( \\
\hline Pnoto 11 & Group II & 108 & 3.52 & 2.24 & $1 . / 2$ & 208.00 & 0.09 \\
\hline
\end{tabular}

Group I- Intermediate and lower; Group II- Advanced and higher

perceived value and satisfaction. Previous studies indicate that an increase in perceived value and satisfaction has positive effects on loyalty and the possibility to revisit the place [34]. Qualities of routes and purity of the natural environment are the other important factors that affect the motivation of climbers [35]. This is why insufficient precautions and the negative impacts of visitors on nature and climbing routes will naturally have negative impacts on visitor/climber experiences. In the visual preference study, carried out by Jones [12] in Rock Canyon, 16 photographs were used to determine the ideas of 143 participants. According to the study, participants had more positive views about the photographs in which there are no bolts. On the other hand, according to the results of the very same study, chalk use didn't have any statistically significant visual impact. In the study by Waldrup and McEwen [36] in Red Rock Canyon, it was determined that climbers didn't find the use of bolt and chalk irritating; field administrators and other visitors defined these two factors as 'problems'. According to the results of this study, an increase in the use density of chalk on rocks decreases the perceived visual quality and climbing willingness of climbers. In this respect, it is determined that the density of chalk, namely the amount of use, has a negative impact on perceived visual quality; it is important to note that the negative effect isn't caused by just the use of chalk. An increase in the proficiency of climbers increases their dependency on resources and decreases their sensitivity about the effects they personally have on nature [37]. In the frame of this information, the effects of the experience and proficiency level of participants on their perceived visual quality and climbing willingness on the basis of the chalk density on rocks, are analyzed. At the end of the study, it is found that their experience didn't affect the perceived visual quality and climbing willingness, while their climbing proficiency affected perceived visual quality and climbing willingness. An increase in chalk density on climbing routes decreased advanced and higher-level climbers' perceived visual quality and willingness. The climbing willingness of participants with high proficiency changed from positive to negative specifically in the photographs with high levels of chalk use (photographs 10 and 11). On the other hand, while climbing willingness of participants with intermediate and lower climbing proficiency decreased, they didn't have a negative climbing willingness even in the photograph with the highest level of chalk use. This result is contrary to the idea that the increase in the proficiency of climbers decreases their environmental sensibility [37]. This contradiction in the two views might be the result of the samples in these studies. While the sampling of the other study is defined as "climbers" in general, this study is specifically practiced with sports climbers. At this point, it is important to note that the definition of climber can be used for mountaineers and rock climbers. Additionally, the expression of a rock climber can be divided into two 
types as traditional climbers and sports climbers; these two groups have different approaches and practices [37]. Analysing the differences between traditional and sports climbers in future studies can make significant contributions to the literature.

As a result, besides the negative visual impact of the use of material, an increase in the density/amount of it may negatively affect the climbing willingness of climbers. It is generally considered that negative results of outdoor recreations are inevitable results [38]; however, direction and dimension of these impacts are closely connected to the visitor behaviours and administrative approaches in the area. Within this scope, to ensure the sustainability of natural environments, it is necessary to make plans for preventing and reducing the negative effects and informing visitors on the basis of these plans. It is known that while climbers have the tendency to give importance to natural life and environment, they don't generally support the existence of official authorities in these fields [19]. Recreations and field managers should improve administrative activities and they should cooperate with users like rock climbers to minimize the negative effects of outdoor activities, protect natural resources and increase the quality of recreation experiences [39]. In this context, it is believed that informing climbers about the negative effects of chalk use level, directing them towards the use of materials that will leave less serious marks on climbing routes (coloured chalk, liquid chalk, etc.) or suggesting them clean the route with brush after climbing can decrease the negative impacts of these activities on nature. On the other hand, it is suggested that routes that are commonly used by climbers are cleaned by workers appointed by field managers.

\section{Acknowledgement}

There is no financial support in the research.

\section{Conflict of interest}

The authors declare that there is no conflict of interests.

\section{References}

1. Lorite J, Serrano F, Lorenzo A, Cañadas EM, Ballesteros M, Peñas J. Rock climbing alters plant species composition, cover, and richness in Mediterranean limestone cliffs. PLOS ONE, 2017; 12(8): 1-14. https://doi.org/10.1371/journal.pone.0182414

2. Bowker JM, Askew AE, Cordell HK, Betz CJ, Zarnock SJ, Seymour L. Outdoor Recreation Participation in the United States-Projections to 2060: A Technical Document Supporting the Forest Service 2010 RPA Assessment [Internet]. Southern Research Station, Asheville, NC: General Technical Report SRS-160, US Department of Agriculture Forest Service; 2012. [cited 2020 Mar 5]. Available from: https://www.srs.fs.fed.us/pubs/gtr/gtr srs160.pdf

3. DAV Duetscher Alpenverein [Internet]. DAV Duetscher Alpenverein; 2020. [cited 2020 Feb 1]. Available from: https://www.alpenverein.de/wettkampf/klettern-bouldernspeedklettern/sportklettern-und-wettkaempfe-beim-dav aid 10318.html

4. McMillan MA, Larson DW. Effects of rock climbing on the vegetation of the Niagara Escarpment in Southern Ontario, Canada. Conservation Biology, 2002; 16(2): 389-398. https://doi.org/10.1046/j.1523-1739.2002.00377.x

5. Vogler F, Reisch, C. Genetic variation on the rocks - the impact of climbing on the population ecology of a typical cliff plant. Journal of Applied Ecology, 2011; 48: 899-905. https://doi.org/10.1111/j.1365-2664.2011.01992.x

6. Clark P, Hessl A. The effects of rock climbing on cliff-face vegetation. Applied Vegetation Science, 2015; 18: 705-715. https://doi.org/10.1111/avsc.12172

7. Tessler M, Clark TA. The impact of bouldering on rock-associated vegetation. Biological Conservation, 2016; 204: 426-433. https://doi.org/10.1016/j.biocon.2016.10.004

8. HolzschuhA. Doesrockclimbing threaten cliffbiodiversity?-A critical review. Biological Conservation, 2016; 204: 153-162. https://doi.org/10.1016/j.biocon.2016.10.010

9. Huddart D, Stott T. Outdoor Recreation Environmental Impacts and Management. Cham: Springer Nature; 2019.

10.Sevenant M, Antrop M. Cognitive attributes and aesthetic preferences in assessment and differentiation of landscapes. Journal of Environmental Management, 2009; 9: 2889-2899. https://doi.org/10.1016/j.jenvman.2007.10.016

11.Tyrväinen L, Silvennoinen H, Hallikainen V. Effect of the season and forest management on the visual quality of the nature-based tourism environment: a case from Finnish Lapland. Scandinavian Journal of Forest Research, 2017; 32(4): 349-359. https://doi.org/10.1080/02827581.2016.1241892

12.Jones CD. Evaluating visual 1mpacts of near-view rock climbing scenes. Journal of Park and Recreation Administration, 2004; 22(3): 39-49.

13.Baker B. Controversy over use of rock-climbing anchors may be missing the mark. BioScience, 1999; 49(7): 529. https://doi.org/10.1093/bioscience/49.7.529

14.Jones CD, Hollenhorst SJ, Hammitt WE. Assessing the social construction of visual-spatial preferences for wilderness impacts. Journal of Park and Recreation Administration, 2004; 22(3): 50-68.

15.Borden DS, Mahamane S. Social marketing and outdoor recreational advocacy groups: Lessons from a rock climbing campaign. Journal of Outdoor Recreation and Tourism, 2020; 29, 100262. https://doi.org/10.1016/j.jort.2019.100262

16.LiFX, Margetts S, FowlerI.Use of 'chalk'in rock climbing: sine quanonormyth? JournalofSports Sciences, 2001;19,427-432. https://doi.org/10.1080/026404101300149375

17.Kilgas MA, Drum SN, Jensen RL, Philips KC, Watts PB. The effect of magnesium carbonate (chalk) on geometric entropy, force, and electromyography during rock climbing. Journal of Applied Biomechanics, 2016; 32: 553-557. https://doi.org/10.1123/jab.2016-0009

18. Wood KT, Lawson SR, Marion JL. Assessing recreation impacts to cliffs in Shenandoah National Park: Integrating visitor observation with trail and recreation site measurements. Journal of Park and Recreation Administration, 2006;24(4): 86-110.

19.Monz CA. Climbers' attitudes toward recreation resource impacts in the Adirondack Park's Giant Mountain Wilderness. International Journal of Wilderness, 2009; 15(1): 26-33. 
20.Martin S, McCool S, Lucas R. Wilderness campsite impacts: Do managers and visitors see them the same? Environmental Management, 1989; 13: 623-629. https://doi.org/10.1007/BF01874968

21.Shelby B, Shinder B. Interest group standards for ecological impacts at wilderness campsites. Leisure Sciences, 1992; 14, 17-27. https://doi.org/10.1080/01490409209513154

22.Manning R, Jacobi C, Marion JL. Recreation monitoring at Acadia National Park. The George Wright Forum, 2006; 23(2): 59-72.

23.Eriksson L, Nordlund AM, Olsson O, Westin K. Recreation in Different Forest Settings: A Scene Preference Study. Forests, 2013; 3: 923-943. https://doi.org/10.3390/f3040923

24.Arnberger A, Ebenberger M, Schneider IE, Cottrell S, Schlueter AC, Ruschkowski E, et al. Visitor preferences for visual changes in Bark Beetle-impacted forest recreation settings in the United States and Germany. Environmental Management, 2018; 61: 209-223. https://doi.org/10.1007/s00267-017-0975-4

25.Manning R, Freimund W. Use of visual research methods to measure standards of quality for parks and outdoor recreation. Journal of Leisure Research, 2004; 36(4): 557-579. https://doi.org/10.1080/00222216.2004.11950036

26.Brown TC, Daniel, TC, Richards MT, King DA. Recreation participation and the validity of photo-based preference judgments. Journal of Leisure Research, 1988; 20: 40-60. https://doi.org/10.1080/00222216.1989.11969789

27.Hill D, Daniel, TC. Foundations for an ecological aesthetic: Can information alter landscape preferences? Society \& Natural Resources, 2007; 21(1): 34-49. https://doi.org/10.1080/08941920701655700

28.Daniel TC, Smidt, RK. Assessing the validity and reliability of descriptor variables used in scenic highway analysis. Landscape and Urban Planning, 2004; 66(4): 239-255. https://doi.org/10.1016/S0169-2046(03)00114-2

29.Acar C, Kurdoglu BC, Kurdoglu O, Acar H. Public preferences for visual quality and management in the Kackar Mountains National Park (Turkey). International Journal of Sustainable Development \& World Ecology, 2006; 13(6): 499-512.
30.George D, Mallery P. SPSS for Windows Step by Step: A Simple Guide and Reference 17.0 update. Boston: Pearson; 2010.

31.Manning RE. Parks and carrying capacity: Commons without tragedy. Washington, DC: Island Press; 2007.

32.Gibson AW, Newman P, Lawson S, Fristrup K, Benfield JA, Bell PA, Nurse GA. Photograph presentation order and range effects in visual-based outdoor recreation research. Leisure Sciences, 2014; 36: 183-205. https://doi.org/10.1080/01490400.2013.862886

33.Draper N, Giles D, Schöffl V, Konstantin Fuss F, Watts $\mathrm{P}$, Wolf $\mathrm{P}$, et al. Comparative grading scales, statistical analyses, climber descriptors and ability grouping: International Rock Climbing Research Association position statement. Sports Technology, 2016; 8(3-4): 88-94. https://doi.org/10.1080/19346182.2015.1107081

34.Chen CF, Chen FS. Experience quality, perceived value, satisfaction and behavioral intentions for heritage tourists. Tourism Management, 2010; 31(1): 29-35. https://doi.org/10.1016/j.tourman.2009.02.008

35.Ansari AM. Understanding the motivations of rock climbers: A social worlds study. Las Vegas: University of Nevada; 2008.

36.Waldrup R, McEwen D. Rock-climbing and wilderness: a study of climber's attitudes toward wilderness, climbing impacts and regulation. Trends, 1994; 3: 38-42.

37.Bryan H. Conflict in the great outdoors. Alabama: University of Alabama Press, Bureau of Public Administration; 1979.

38.Schuster RM, Thompson JG, Hammitt WE. Rock Climbers' attitudes toward management of climbing and the use of bolts. Environmental Management, 2001; 28(3): 403-412. https://doi.org/10.1007/s002670010232

39. Marion JL, Leung Y, Eagleston H, Burroughs K. A Review and synthesis of recreation ecology research findings on visitor impacts to wilderness and protected natural areas. Journal of Forestry, 2016; 114(3): 352-362. https://doi.org/10.5849/jof.15-498

40.Schwartza F, Taffa BD, Lawhon B, Pettebone D, Esser S, D'Antonio A. Leave No Trace bouldering ethics: Transitioning from the gym to the crag. Journal of Outdoor Recreation and Tourism, 2019; 25: 16-23. https://doi.org/10.1016/j.jort.2018.11.003

\section{Information about the authors:}

Güney Çetinkaya; (Corresponding Author); https://orcid.org/0000-0002-1757-5105; gcetinkaya@akdeniz.edu.tr; Department of Recreation, Faculty of Sport Sciences, Akdeniz University, Antalya, Turkey.

Abdullah Güngör; https://orcid.org/0000-0002-2021-209X; abdullahgngr@gmail.com; Department of Recreation, Faculty of Sport Sciences, Akdeniz University, Antalya, Turkey.

Dicle Aras; https://orcid.org/0000-0002-9443-9860; diclearax@gmail.com; Ankara University Faculty of Sport Sciences, Golbasi, Ankara, Turkey.

Cite this article as:

Çetinkaya G, Güngör A, Aras D. Impact of the "Chalk" on perceived visual quality and the willingness to climb: a research on sports climbing. Pedagogy of Physical Culture and Sports, 2021;25(1):15-23. https://doi.org/10.15561/26649837.2021.0103

This is an Open Access article distributed under the terms of the Creative Commons Attribution License, which permits unrestricted use, distribution, and reproduction in any medium, provided the original work is properly cited (http://creativecommons.org/licenses/by/4.0/deed.en).

Received: 24.06.2020

Accepted: 02.08.2020; Published: 25.02.2021 